\title{
Influence of climate variables on resin yield and secretory structures in tapped Pinus pinaster Ait. in central Spain
}

\author{
Aida Rodríguez-García ${ }^{a}$, Juan Antonio Martín ${ }^{\mathrm{a}, *}$, Rosana López ${ }^{\mathrm{a}, *}$, Sven Mutke ${ }^{\mathrm{b}, \mathrm{c}}$, \\ Felix Pinillos ${ }^{\mathrm{d}}$, Luis Gil ${ }^{\mathrm{a}}$ \\ ${ }^{a}$ Forest Genetics and Physiology Research Group, School of Forest Engineering, Technical University of Madrid (UPM), Ciudad Universitaria s/n, 28040 \\ Madrid, Spain \\ ${ }^{\mathrm{b}}$ INIA-CIFOR, Forest Research Centre, Crta. de la Coruña km 7,5, 28040 Madrid, Spain \\ c SFM-RI, Sustainable Forest Management Research Institute UVa INIA, Madrid, Spain \\ d CESEFOR, Forestry Services and Promotion Centre of Castilla y León, Polígono Industrial “Las Casas”, Calle C, Parcela 4, 42005 Soria, Spain
}

\section{A R T I C L E I N F O}

\section{Article history:}

Received 8 July 2014

Received in revised form

21 November 2014

Accepted 30 November 2014

Available online 26 December 2014

\section{Keywords:}

Resin canal

Resin flow

Water status

Xylem anatomy

Non-wood forest products

Mediterranean climate

\begin{abstract}
A B S T R A C T
In the last five years, sharp increases in the price of natural resins, accompanied by technological advances directed toward mechanization, have made resin tapping a strategic activity for rural development and forest conservation. The resin industry demands more efficient tapping methods and forest management plans as a way to increase competitiveness in a global market. Understanding the effects of environmental conditions on resin yield, especially under the current scenario of climate change, is key to improving techniques and plans in the resin industry. This study aims to evaluate the intra- and inter-annual effects of climate conditions and soil water availability on resin yield in tapped Pinus pinaster stands. The individual resin yield of 26 tapped trees growing at two locations with different stand densities and soil characteristics was measured fortnightly during the tapping season (June to October) for four years. The study was complemented with an analysis of changes in xylem anatomy over the four years, with a focus on axial resin canal traits, including 12 non-tapped trees as controls. Intra-annual variation in resin yield was strongly correlated with temperature, solar radiation, potential evapotranspiration and water deficit. Inter-annual variation in resin yield and resin canal abundance were correlated with temperature and water deficit in spring, but above a certain threshold of cumulated water deficit in summer rainfall favored resin yield. Under adverse climate scenarios where resource optimization is desirable, a reduced tapping season during the warmest months (June-September) would be advisable, assuming a very small production loss. Similarly, in years with a rainy summer and/or dry spring, a slightly longer tapping season could be suggested, as resin yield increases after these events.
\end{abstract}

(c) 2014 Elsevier B.V. All rights reserved.

\section{Introduction}

Resin exudation is the main defense mechanism of pine trees againts bark boring insects and fungal pathogens (Lieutier, 2004; Franceschi et al., 2005), and can be induced by other external factors such as abiotic stress, application of chemical stimulants, or mechanical wounding (Croteau et al., 1987; Ruel et al., 1998; Nagy et al., 2000; Franceschi et al., 2002; Moreira et al., 2012). Resin

\footnotetext{
* Corresponding authors. Tel.: +34 $913367113 /+34913367103$.

E-mail addresses: aidargvaldes@hotmail.com (A. Rodríguez-García), juan.martin.garcia@upm.es (J.A. Martín), rosana.lopez@upm.es (R. López), mutke@inia.es (S. Mutke), felix.pinillos@cesefor.com (F. Pinillos), luis.gil@upm.es (L. Gil).
}

extraction through mechanical wounding to produce tar for ship caulking was a traditional forest use in the Mediterranean basin that began in Classical times. It led to major deforestation, mainly of coastal pine woods, that would continue in subsequent historical periods (Valbuena-Carabaña et al., 2010; Mutke et al., 2013). In the 19th century, resin tapping from living trees began as a nondestructive extraction method and became very important in the rural economy of Southern Europe (Hernández, 2006). Resin was considered to be the most versatile material in the preindustrial world (Langenheim, 2003) and continues to be the raw material for a wide range of industrial products and one of the most important non-timber forest products (Hall et al., 2013). Maritime pine (Pinus pinaster Ait.) has been the most common tapping tree in recent centuries and is now the only species tapped in western Mediterranean countries. In this region it is one of the main forest trees and 
comprises the most extensive conifer forests in Spain, Portugal and southern France (Gil et al., 1990). In Spain, 20 regions of provenance with a wide range of ecological conditions have been defined for $P$. pinaster. This species presents high genetic variability in neutral and adaptive traits (Gil et al., 2010; Morales-Molino et al., 2012) and provenances of $P$. pinaster show considerable differences in terms of resin production (Alía et al., 1995; Nanos et al., 2000).

The resin industry of southern Europe demands more efficient tapping methods and forest management plans to increase supply and enhance competitiveness in a global market (Cunningham, 2013). Understanding the intra- and inter-annual effects of climate conditions and soil water availability on resin yield in pine stands used for tapping is essential for improving techniques and plans in the resin industry. This becomes particularly important in the current scenario of climate change, where projections in the Mediterranean region indicate more frequent extreme climate conditions, which could alter water availability and impact delivery of ecosystem services (Terrado et al., 2014). Climate projections for the Mediterranean region predict a pronounced decrease in precipitation (especially in the warm season), more extended droughts, marked warming reaching a maximum in summer, concentration of rainfall in shorter periods of the year, and a greater occurrence of extremely high temperature events (Giorgi and Lionello, 2008). Negative effects of the already ongoing climate change on nonwood forest products, such as Mediterranean pine nuts, has been described for Central Spain in the middle basin of the Douro River (Mutke et al., 2005). Climate change may also have unpredictable effects on resin production, although research has shown that climate conditions can affect resin flow in two main ways: directly, because temperature changes resin fluidity (Pardos et al., 1976; Hodges et al., 1979; Blanche et al., 1992), and indirectly, because climate factors, such as temperature and water stress, have a major effect on tree anatomical structure and the physiological processes involved in resin biosynthesis and secretion (Blanche et al., 1992; Ruel et al., 1998; Baier et al., 2002; Tingey et al., 1980; Lombardero et al., 2000; Génova et al., 2014). As positive relationships exist between resin flow (as plant secondary chemistry) and pest resistance (e.g. Mumm and Hilker, 2006; Kolosova and Bohlmann, 2012), the described climate effects on resin flow could be directly applicable to the tree defence capacity against bark boring insects and fungal pathogens.

The process of resin exudation is mediated by anatomical and metabolic changes in the secretory structures known as resin canals, which occur in the outer layer of the earlywood and in the latewood of tree rings (Boschiero and Tomazzello-Filho, 2012). These changes include the formation of traumatic resin canals (Wimmer and Grabner, 1997; Martin et al., 2002; Luchi et al., 2005) and the synthesis of new resin in epithelial cells to refill constitutive canals (Ruel et al., 1998; Phillips and Croteau, 1999; Krokene and Nagy, 2012). The relations between resin yield and resin canals traits in P. pinaster were recently studied (Rodríguez-García et al., 2014). In tapped trees, an increase in axial canal frequency and area per $\mathrm{mm}^{2}$ of cross section was found during the three years following the start of tapping activity, suggesting that canal formation is a systemic induced response to wounding. In high yielding trees, the area of axial canals per $\mathrm{mm}^{2}$ of cross section was directly related to resin yield in certain locations, as were resin canal volume per growth ring unit and radial canal frequency (Rodríguez-García et al., 2014). It is likely that a complex interaction system exists between climate, tapping wound, resin flow and tree anatomical and physiological features. Similarly, significant variations are expected to exist, e.g. between different species, provenances, climates, resinflow inducing treatments, age classes and stand structures (Nanos et al., 2001; Roberds et al., 2003; Rodrigues et al., 2008). Most studies on resin flow have been conducted under controlled conditions, opening small wounds for a short period (Lombardero et al., 2000;
Gaylord et al., 2007; Novick et al., 2012) in saplings or young trees (Ruel et al., 1998; Roberds et al., 2003; Knebel et al., 2008). In this study, we aim to evaluate climate effects on the resin production of mature trees tapped for five years, corresponding to real-scale tapping activity. In temperate zones, tapping activity is seasonal; e.g. in the Mediterranean area it starts any time from March-June and finishes in October or November. Peak resin flows usually occur in late spring and during summer months (Pio and Valente, 1998; Kim et al., 2005; Gaylord et al., 2007).

The growth-differentiation balance hypothesis (Herms and Mattson, 1992; Gaylord et al., 2007; Novick et al., 2012) states that there is a tradeoff between growth-related and differentiationrelated processes (e.g. the production of defensive compounds) in plants. To produce chemical defenses (e.g. resin) the plant needs energy from photosynthesis, but the peak concentrations of secondary metabolites are reached in scenarios of moderate level of available resources (e.g. water and nutrients), when growth is limited. In situations where resource availability limits photosynthesis, both growth and defense are limited. According to this theoretical framework, it is hypothesized that during suboptimal conditions for growth, e.g. periods of moderate water stress, resin yield is increased in $P$. pinaster stands. In $P$. taeda, peak resin flows appeared to be associated with moderate water deficit periods (Ruel et al., 1998; Lombardero et al., 2000). Furthermore, earlier studies on Pinaceae xylem anatomy showed that harsh environmental conditions such as high temperatures, aridity and cold winters are associated with higher frequencies and greater sizes of resin canals (Zamski, 1972; Rigling et al., 2003; Martín et al., 2010; Esteban et al., 2010), whereas an increment of annual or summer rainfall is negatively correlated with these traits (Wimmer and Grabner, 1997; O'Neill et al., 2002). Thus it is also hypothesized that constitutive and traumatic resin canal formation and de novo resin synthesis processes will be influenced by the climate characteristics of the current and the previous year. Years with high radiation (favoring photosynthesis processes), high summer temperatures (delaying radial resin canal sealing), and low rainfall (inducing resin canal formation) will be highly productive or determine high resin production in the following year. During the tapping season, warm springs and summers with low humidity percentages could correspond to higher resin yield values.

This study examines the climate variables that affect resin yield and the anatomical traits related to resin yield. The aims were to (i) identify the most influential climate variables and the effect of soil water status in intra-annual variation of resin yield in trees growing in two different locations with different stand densities; (ii) evaluate how inter-annual variations in climate conditions and soil water storage affect annual resin yield, and (iii) relate these variations to changes in wood anatomical structures, with a focus on $P$. pinaster's defense system. Possible tapping management implications for future climate scenarios are discussed.

\section{Materials and methods}

\subsection{Study area and climate data}

The trees studied are located in two $P$. pinaster forests $16 \mathrm{~km}$ apart in the province of Segovia, Spain. Maritime pine occupies more than 200,000 ha in this part of the middle basin of the Douro River, on a flat highland 700-950 m above sea level in central Spain. The area is covered by sandy plains, dune systems, cereal crops and patches of pine forest ( $P$. pinaster and $P$. pinea). It is known as Tierra de Pinares (Pine Woodlands) because of the forest that remains due to the poor fertility of the soil and reforestation of communally owned deforested land in the 19th and 20th centuries using local provenances. The two stands studied, near the 
villages of Armuña and Melque, are geographically close and at the same altitude $(900 \mathrm{~m})$. They have similar climates but their stand densities differ and the trees were tapped in different years (2006-2010 in Melque and 2007-2011 in Armuña). Mean annual rainfall in the area is $440 \mathrm{~mm}$ and the dry period lasts about four summer months. Monthly mean minimum and maximum temperatures (from Aranda de Duero weather station, a 42-year climate series, $80 \mathrm{~km}$ from the stands) range from 2.0 to $5.8^{\circ} \mathrm{C}$ and 18.8 to $23.1^{\circ} \mathrm{C}$, respectively. The soils are Quaternary deposits of alluvial sedimentary materials, mainly siliceous oligotrophic, and are poorly developed (arenosol, psamment). The soil texture is loamy sand in Armuña and sandy in Melque for the first $25 \mathrm{~cm}$, although unevolved sands are reached at around $1 \mathrm{~m}$ in depth in both locations (Rodríguez-García et al., 2014).

Climate data for the area studied were compiled from Nava de la Asunción weather station, which is $15 \mathrm{~km}$ from the Melque stand and $18 \mathrm{~km}$ from the Armuña stand and at the same altitude. This station has a 14-year climate series (Fig. 1) but it was chosen for our study instead of the Aranda de Duero station, which has a longer series, because of proximity. Mean cumulated annual rainfall was $469 \mathrm{~mm}$ and mean temperature was $11.15^{\circ} \mathrm{C}$ for the 2000-2013 climate series. For the yield variation analysis within and between years, the climate variables studied were: daily radiation, mean daily temperature, daily rainfall $(P)$ and humidity, and daily estimated potential evapotranspiration (PET) calculated by the State Meteorology Agency of Spain (AEMET) according to the Penman-Monteith method (FAO, 1998). Daily rainfall and potential evapotranspiration were used to calculate four soil water status variables - actual evapotranspiration (AET), soil water content (WC), water deficit (D), and cumulated water deficit (CD) - using the Thornthwaite and Mather model (Botey et al., 2009) for the years studied (2007-2010) as follows:

$$
\begin{aligned}
\mathrm{WC}_{i}= & \min \left[\left(\mathrm{WC}_{i-1}+P_{i}-E_{i}\right), \mathrm{WCt}\right] \\
& \text { if } P_{i}>\mathrm{PET}_{i} \quad E_{i}=\mathrm{PET}_{i} \\
& \text { if } P_{i}<\mathrm{PET}_{i} \quad E_{i}=P_{i}+\left[\mathrm{WC}_{i-1}\left(1-\exp ^{\left[\left(P_{i}-\mathrm{PET}_{i}\right) / \mathrm{WC}\right]}\right)\right] \\
\mathrm{AET}_{i}= & P_{i}+\left|\mathrm{WC}_{i}-\mathrm{WC}_{i-1}\right| \\
D_{i} \quad=\mathrm{PET}_{i}-\mathrm{AET}_{i} & \\
X_{i} \quad= & \text { measure of the ith day } i=1, \ldots, n
\end{aligned}
$$

Available water storage capacity (WCt) was estimated to be the same for both sites: $100 \mathrm{~mm}$ water/m soil (Water Conservation Factsheet, 2002) (Table 2), given the results of previous soil characterizations of the studied stands (Rodríguez-García et al., 2014). For the inter-annual analysis only, calculations were made of the number of months each year with certainty of frost (Cf), i.e., the number of months when the mean minimum temperature is below $0^{\circ} \mathrm{C}$, and the duration of aridity (a), i.e., the number of months when the temperature curve was above the rainfall curve in the Gaussen climogram (Fig. 1).

\subsection{Resin yield measurements}

The trees used in this study were part of two experimental plots designed by the Forestry Services and Promotion Centre of Castilla y León (CESEFOR) as part of a program to improve resin tapping in Central Spain. The plots were even aged, ca. 75 years old. Approximately 400 trees were tapped for five years: 197 in Melque (2006-2010) and 201 in Armuña (2007-2011). For the study, we used the resin yield data corresponding to the four-year period when trees were tapped in both locations (2007-2010). The tapping method comprised cutting horizontal grooves every fortnight, advancing upward from the first groove at $20 \mathrm{~cm}$ above the ground
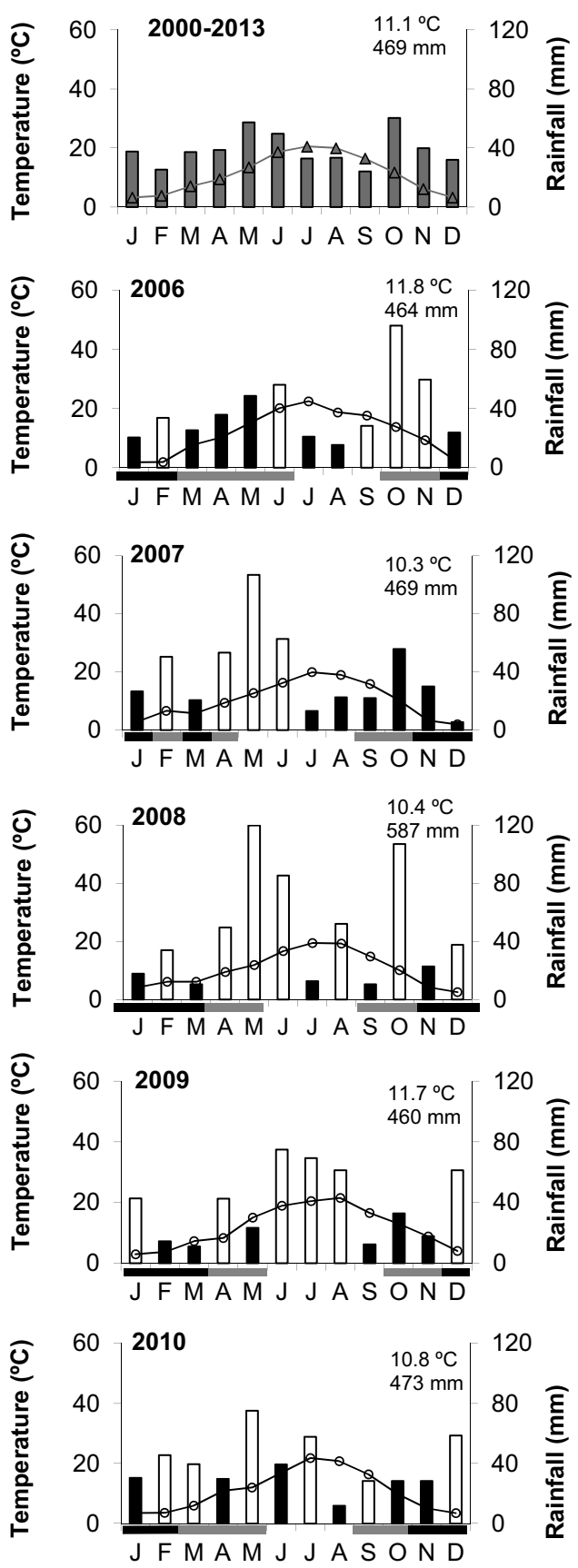

Fig. 1. Mean monthly temperature and rainfall for the period 2000-2013 (gray line and gray bars) are shown in the first graph. The following five graphs show mean monthly temperature and rainfall for the years 2006-2010 (black line and black and white bars). White bars represent mean monthly values higher than the mean value of the 2000-2013 period and black bars lower mean monthly values. The number of months with certainty of frost (months with mean minimum $<0$ ) is represented by horizontal black bars and the number of months with probability of frost (months with absolute minimum temperatures $<0$ and mean minimum $>0$ ) is represented by horizontal gray bars. Representative climate data for the area studied were compiled using data from Nava de la Asunción weather station, $15 \mathrm{~km}$ from the stands in Melque and and $18 \mathrm{~km}$ from the stands in Armuña, at the same altitude $(900 \mathrm{~m})$.

to final heights of $200-260 \mathrm{~cm}$. The mean length of grooves was approximately $12 \mathrm{~cm}$ and the height varied from $2-3 \mathrm{~cm}$. Bark and phloem were removed and a stimulant paste with $40 \%$ sulfuric acid was applied (40\% sulfuric acid solution and $300 \mathrm{~g}$ gypsum per $1000 \mathrm{~g}$ solution in the final paste). Resin yield was measured fortnightly, before the next groove was cut, by weighing the contents of the cans in which the resin was collected from June to October. 


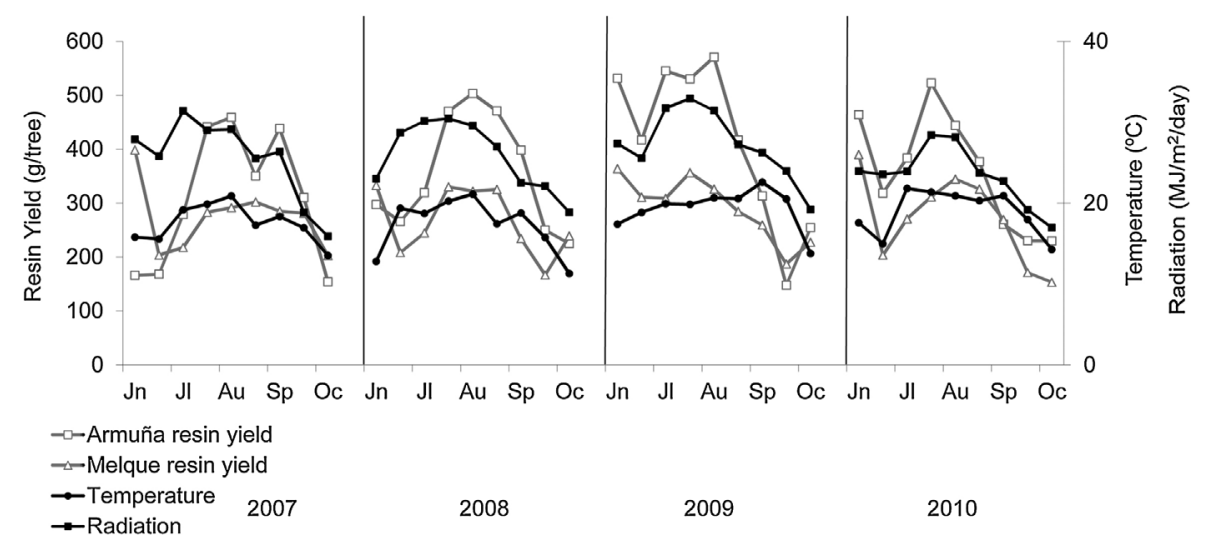

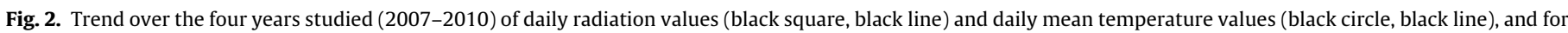
the Armuña and Melque resin yield (gray lines) measured fortnightly during each tapping season and expressed as $g$ per tree.

\subsection{Anatomical measurements}

For anatomical measurements, 26 tapped trees were selected in the experimental plots (14 in Armuña and 12 in Melque). Two wood cores, one from the northern and one from the eastern side, were taken from each tree at breast height (ca. $1.30 \mathrm{~m}$ ) with an increment borer (diameter $=1 \mathrm{~cm}$ ). The cores contained at least the five most recent growth rings (2006-2010). Samples were taken at a minimum distance of $10 \mathrm{~cm}$ from the tapping wound boundary to minimize the local effect of the wound on the xylem tissues (Lev-Yadun, 2002; Ballesteros et al., 2010). Northern and eastern orientations were chosen because they are traditionally regarded as the faces with the lowest (north) and highest (east) resin yield. Cores were stored in 70\% ethanol. Additionally, seven non-tapped trees were chosen in Armuña and five in Melque as controls. These trees were within a $300 \mathrm{~m}$ radius of the tapped trees.

In total, 76 cores were extracted and prepared for light microscopy observation. Transverse sections, $20-30 \mu \mathrm{m}$ thick, were cut from each core using a sliding microtome. Sections were stained with a solution of $1 \%$ safranine and $1 \%$ alcian blue following standard protocols (Heijari et al., 2005) and mounted after dehydrating through an ethanol series. Samples were photographed with a light microscope using a Nikon digital Coolpix 4500 camera and analyzed with WinCELL Pro (version 2004a; Regent Instruments Inc., Quebec City, Canada). The following parameters were measured in the 2007-2010 growth rings: growth ring width, early- and latewood increments $(\mu \mathrm{m})$, mean lumen area of earlyand latewood tracheids $\left(\mu \mathrm{m}^{2}\right)$, frequency of axial canals (number of axial canals per $\left.\mathrm{mm}^{2}\right)$, area of axial canals $\left(\mathrm{mm}^{2}\right)$ per cross section unit, and mean size of axial canals $\left(\mu \mathrm{m}^{2}\right)$. Epithelial and parenchyma cells adjacent to the resin canals were included in the canal measurements. Mean values per tree and year (growth ring) were calculated for each variable.

\subsection{Statistical analyses}

Linear correlation and regression analyses were performed between climate, resin yield and anatomical variables. First, an intra-annual analysis was performed to analyze the correlation between the fortnightly resin yield and the average values of the climate variables for the same period. These data were obtained throughout the tapping season (June-October) for the period studied (2007-2010). For this analysis, 11 climate variables were selected (Table 2) as those most likely related to the resin flow process during the season (Rodrigues and Fett-Neto, 2012 and references therein). Second, the inter-annual relation between climate and resin yield was analyzed, considering the mean annual resin yield of each tapped tree $(n=398)$ for the years studied and the 11 climate variables shown in Section 2.1. These 11 climate values were analyzed taking into consideration the mean values of the period that would have been most likely to affect the resin yield processes (from January to the end of the tapping season, at the beginning of October), as well as the mean values for the whole previous year. The mean annual values and mean monthly values of the climate variables were related to the mean annual resin yield to determine the most relevant variables and the time of year when these variables have most influence on resin yield.

Mean values of anatomical variables per year (2007-2010 growth rings) and tree $(n=33)$ were used to study the relations between anatomical and climate variables. Means were compared using Fisher's least significant difference test (LSD, $\alpha=0.05$ ). These values were related to the same 11 climate variables corresponding to the current season affecting the wood formation processes (January-September) and the mean value of the whole previous year. All statistical analyses were performed with STATISTICA 7.0 (StatSoft Inc., Oklahoma, USA).

\section{Results}

\subsection{Resin yield and anatomy traits}

Resin yield per tree was higher in the less densely populated stand (Armuña), even though mean resin yield per ha was higher in Melque, the location with higher pine density (Table 1). At both locations the height of dominant and co-dominant trees was the same and therefore both stands had a similar site index (Hanson et al., 2003; Bravo-Oviedo et al., 2007), but the diameter at breast height (Dbh) and the live crown percentage were higher in Armuña $(p<0.05$; Table 1). The locations had the same annual resin yield trend throughout the tapping season for all the years studied: an initially high value was followed by a rapid drop that soon recovers in a bell-shaped curve, reaching peak values at the beginning of August (Fig. 2). In Melque, however, the fortnightly resin yield showed fewer variations than in Armuña (Fig. 2). The most productive year was 2009 for both locations (3.71 and $2.62 \mathrm{~kg} /$ tree/year for Armuña and Melque, respectively) and the least productive year was 2008 for Melque (2.39 kg/tree/year) and 2007 for Armuña (2.73 kg/tree/year; 26\% less than 2009) (Fig. 3).

Growth ring (GR) width decreased over the four years and was similar in tapped and non-tapped trees, with a significant difference between the first two tapping years (2007-2008) and the two last years (2009-2010), due to the reduction of both earlywood and latewood (Fig. 4a). Although no significant growth decrease due to tapping was observed, resin canal variables varied between 
Table 1

Location, dendrometry, resin yield and soil characteristics of the two experimental plots of Pinus pinaster in central Spain.

\begin{tabular}{|c|c|c|c|c|c|c|c|c|c|c|}
\hline $\begin{array}{l}\text { Location in } \\
\text { Spain }\end{array}$ & $\begin{array}{l}\text { Geographic } \\
\text { coordinates }\end{array}$ & Area (ha) & $\begin{array}{l}\text { Density } \\
\text { (tree/ha) }\end{array}$ & $\begin{array}{l}\text { Mean resin } \\
\text { yield (kg/tree } \\
\text { year) }^{\mathrm{a}}\end{array}$ & $\begin{array}{l}\text { Mean resin } \\
\text { yield (kg/ha } \\
\text { year) }\end{array}$ & $\operatorname{Dbh}(\mathrm{cm})$ & Height (m) & $\begin{array}{l}\text { Live crown } \\
\text { (\%) }\end{array}$ & $\begin{array}{l}\text { Soil texture } \\
\text { USDA }\end{array}$ & $\begin{array}{l}\text { Soil texture in } \\
\text { first } 25 \mathrm{~cm} \\
\text { depth }\end{array}$ \\
\hline $\begin{array}{l}\text { Melque de } \\
\text { Cercos } \\
\text { (Segovia) }\end{array}$ & $41^{\circ} 4^{\prime}(\mathrm{N}) 4^{\circ} 28^{\prime}(\mathrm{W})$ & 13.01 & 206 & $2.39 \pm 0.5^{* *}$ & $492 \pm 83^{* *}$ & $41 \pm 1.9^{*}$ & $13.2 \pm 0.4$ & $46.7 \pm 2.1^{* *}$ & Sandy & Sandy \\
\hline $\begin{array}{l}\text { Armuña } \\
\text { (Segovia) }\end{array}$ & $41^{\circ} 3^{\prime}(\mathrm{N}) 4^{\circ} 17^{\prime}(\mathrm{W})$ & 26.42 & 108 & $3.21 \pm 0.5$ & $348 \pm 90$ & $47 \pm 2.1$ & $13.5 \pm 0.5$ & $59.9 \pm 2.3$ & Sandy & Loamy sand \\
\hline
\end{tabular}

a Mean yield 2007-2010.

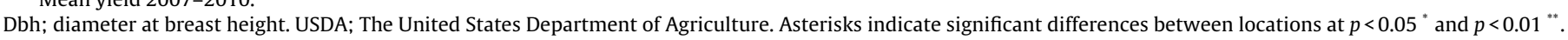

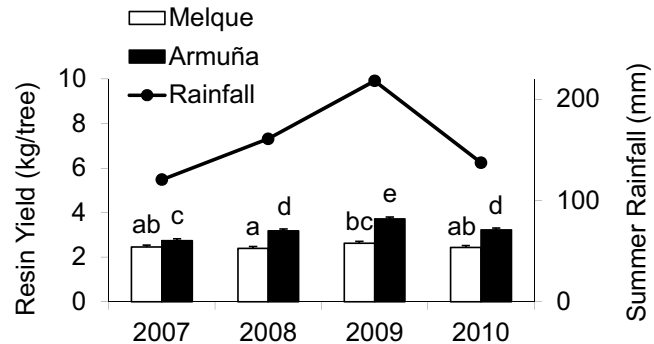

Fig. 3. Mean resin yield expressed as $\mathrm{kg}$ per tree and year for the period 2007-2010 in the two P. pinaster stands studied. Black bars represent Armuña and white bars represent Melque. Identical letters indicate homogeneous groups (LSD comparisons, $\alpha=0.05$ ). Black line represents mean summer rainfall in the current year.

treatments. Axial canal (AC) area per $\mathrm{mm}^{2}$ remained constant in the non-tapped trees, but in the tapped trees a significant increase was detected in 2009 (Fig. 4b). Axial canal frequency showed the same trend $(p<0.03$; data not shown). No traumatic resin canals were found in any of the samples.
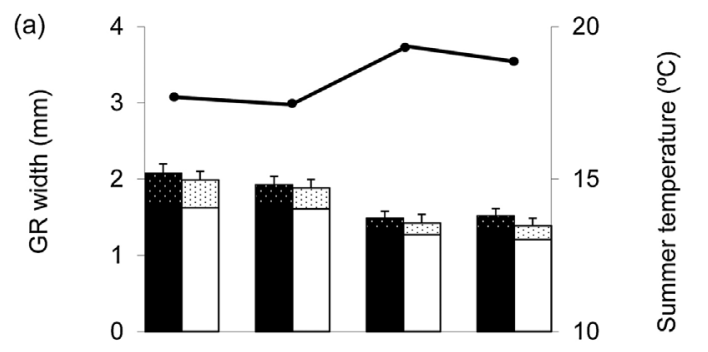

(b)

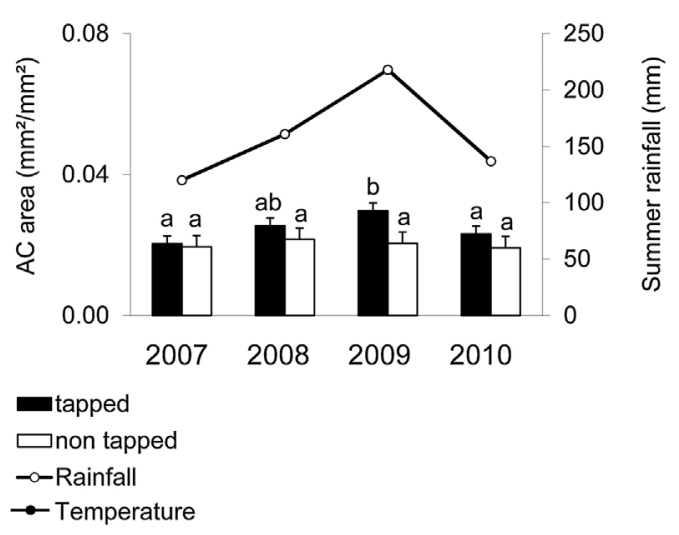

Fig. 4. Growth ring width (a) and area of axial resin canal per $\mathrm{mm}^{2}$ of cross section (b) for the period 2007-2010 in the two P. pinaster stands studied. Black bars represent tapped trees and white bars represent non-tapped trees. In figure (a), gray color in bars represents the latewood width over the total growth ring width and the black line represents the mean annual summer temperature. In figure (b), black line represents mean annual summer rainfall. Identical letters indicate homogeneous groups (LSD comparisons, $\alpha=0.05$ ).
Considering average values per year (data from both locations), the axial canal area (ACa) was related to the mean resin yield in the same $(n)$ and following $(n+1)$ year. In Armuña, no relations between anatomical traits and resin yield were found, while in Melque the area and frequency of axial canals showed significant relations with resin yield in the same and following year (Table 3 ).

\subsection{Climate analysis}

The mean temperature pattern was similar during the four years studied and was also similar to the mean values for the period 2000-2013 (Fig. 1). The tapping season temperature pattern showed differences between the study years (Fig. 2): the highest means were found from late July to early August in 2007 and 2008, from late August to early September in 2009, and from the beginning of July in 2010. Rainfall differed, particularly in spring, showing twice the values in 2007 and 2008 than in 2009 and 2010 (Fig. 5). Similarly, the mean rainfall values for the period 2000-2013 (Fig. 1) affected all the related variables (WC, D, CD and AET); the 2009 spring was the driest and had the highest daily cumulative water deficit $(643 \mathrm{~mm}$ ) despite an atypical rainy summer (Figs. 5 and $6 a$ and b). The dry 2007-2008 winter prevented soil water recharge, although this water deficit in winter and at the beginning of spring 2008 was offset by abundant late spring rainfalls (Figs. 5 and 6b). Throughout the study, there were significant differences between AET and PET, with serious summer droughts. PET reached a maximum in July (ca. $170 \mathrm{~mm}$ ) and followed the same trend over the four years (Fig. 5). AET showed a similar pattern in 2007 and 2008, with sharp peaks and maximum values in June, but in 2009 and 2010 it showed consistently lower values (Fig. 5).

Series of daily soil water storage and cumulative soil water deficits during the tapping season provide more detailed information (Fig. 6a and b). In 2009, water deficit in early June exceeded $200 \mathrm{~mm}$, whereas in the other years it remained below $130 \mathrm{~mm}$. At the beginning of the tapping season in 2009 and 2010, water stored in the soil was only $13-32 \mathrm{~mm}$, due to low spring rainfall, but in the previous years it was 76-83 $\mathrm{mm}$. During the tapping season, the main difference between years was caused by relatively high summer rainfall in 2009, which maintained soil water reserves (Fig. 6b). However, this rain did not compensate for the dry spring, and until October 2009, at the end of the tapping season, the cumulative water deficit was almost $600 \mathrm{~mm}$, whereas in the other three years it was ca. $480 \mathrm{~mm}$ (Fig. 6a). Soil water storage in October 2008 was twice the value for 2007,2009 and 2010 due to autumn rainfall (Fig. 6b).

\subsection{Climate-resin yield relations}

\subsubsection{Intra-annual analysis}

Considering fortnightly values for the four tapping seasons (June to October, 2007-2010), the highest correlations between climate variables and resin yield were found for PET $(r=0.68 ; p<0.001)$ and daily solar radiation $(r=0.64 ; p<0.001)$. Significant positive 


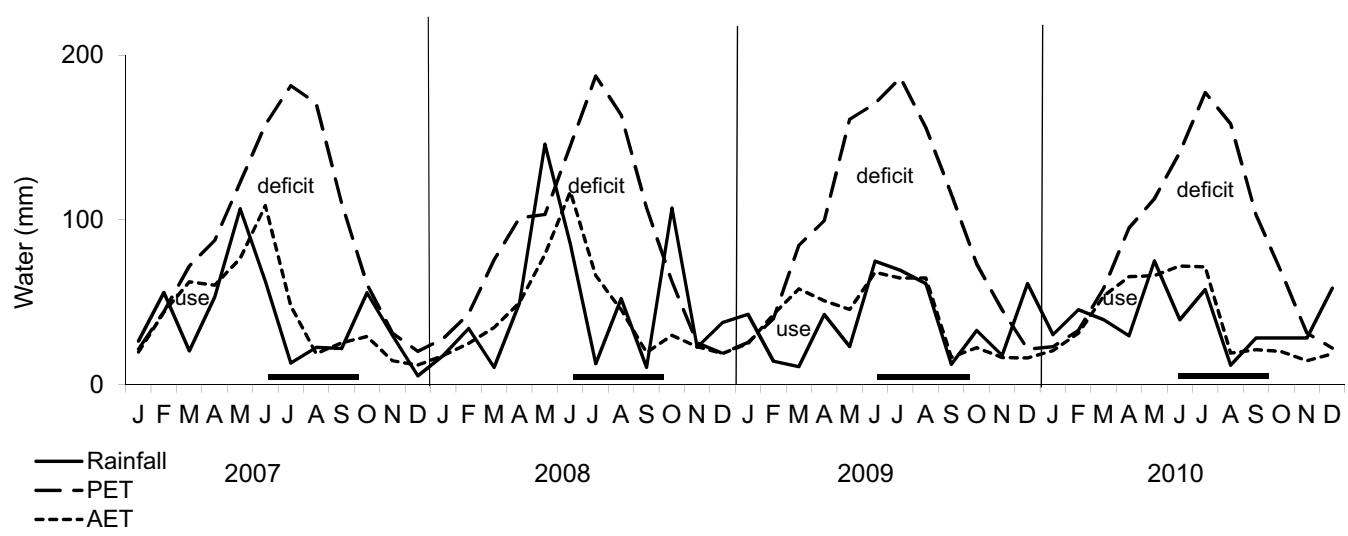

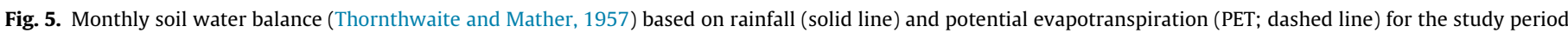

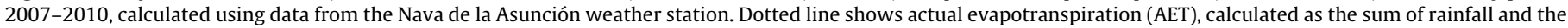

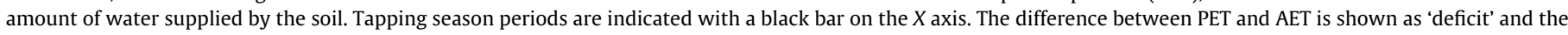
difference between precipitation and AET is the soil moisture utilization, shown as 'use'.

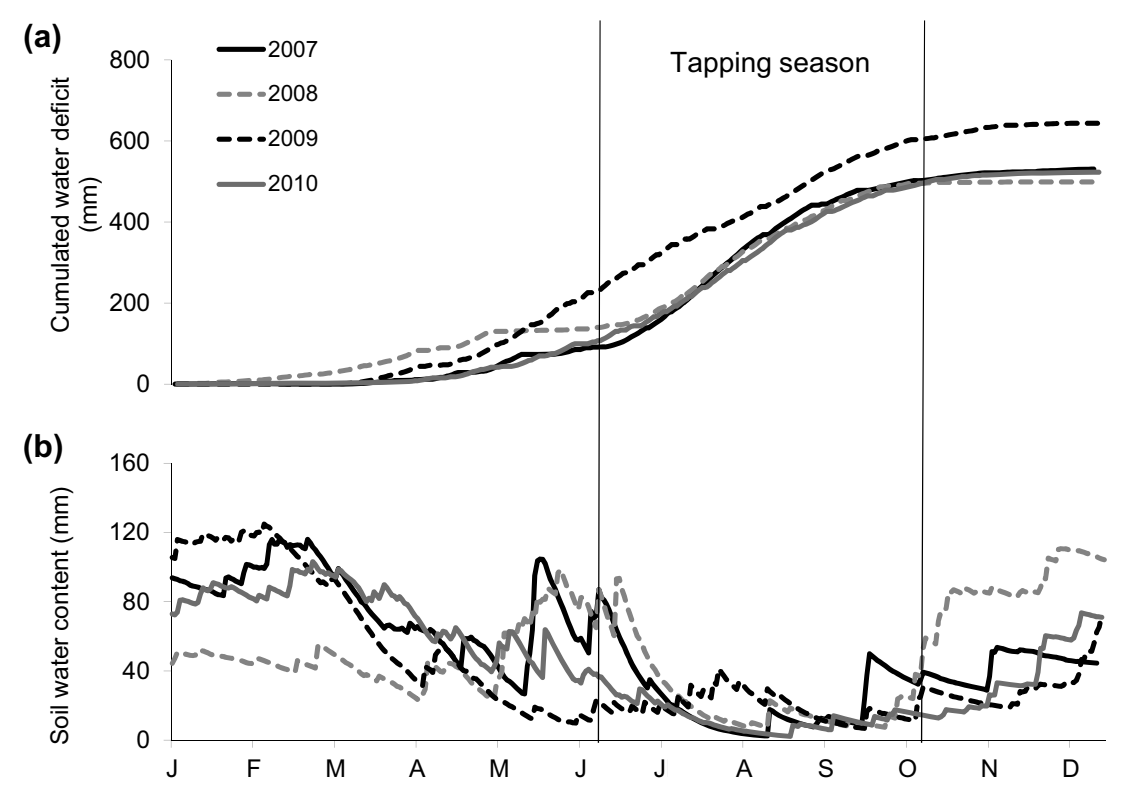

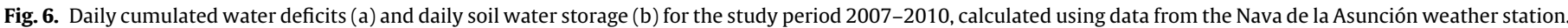
Tapping season periods for each year are indicated within vertical lines.

correlations were found for all the temperature variables, and a negative correlation was found for mean humidity (Table 2). For soil water status, only water deficit showed a significant positive relation to resin yield.
The results for each individual year showed very similar behavior for resin yield in 2009 and 2010, with positive relations to radiation, PET and cumulative water deficit (Table 2). In 2008 we found significant relations only for Armuña, although the general

Table 2

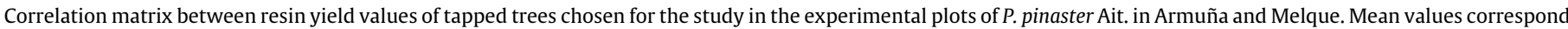

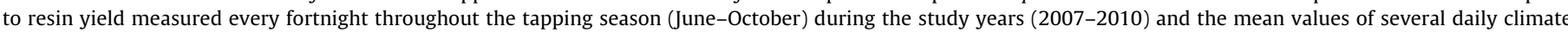
variables for the same period.

\begin{tabular}{|c|c|c|c|c|c|c|c|c|c|c|c|}
\hline \multirow{2}{*}{$\begin{array}{l}\text { Year } \\
\text { Climate variable }\end{array}$} & \multicolumn{3}{|c|}{$2007-2010$} & \multicolumn{2}{|l|}{2007} & \multicolumn{2}{|l|}{2008} & \multicolumn{2}{|l|}{2009} & \multicolumn{2}{|l|}{2010} \\
\hline & Average & Armuña & Melque & Armuña & Melque & Armuña & Melque & Armuña & Melque & Armuña & Melque \\
\hline$T$ mean $\left({ }^{\circ} \mathrm{C}\right)$ & 0.49 & 0.53 & 0.28 & 0.87 & 0.17 & 0.68 & 0.14 & 0.12 & 0.05 & 0.50 & 0.58 \\
\hline Solar radiation $\left(\mathrm{MJ} / \mathrm{m}^{2}\right)$ & 0.64 & 0.63 & 0.51 & 0.41 & 0.28 & 0.58 & 0.38 & 0.81 & 0.72 & 0.88 & 0.76 \\
\hline Mean humidity (\%) & -0.45 & -0.52 & -0.21 & -0.86 & -0.17 & -0.65 & -0.04 & -0.10 & -0.03 & -0.26 & -0.38 \\
\hline Total rainfall (mm) & 0.09 & 0.06 & 0.12 & -0.78 & -0.57 & -0.10 & 0.13 & 0.70 & 0.65 & 0.49 & 0.38 \\
\hline PET $(\mathrm{mm})$ & 0.68 & 0.65 & 0.57 & 0.47 & 0.31 & 0.64 & 0.39 & 0.79 & 0.81 & 0.90 & 0.87 \\
\hline $\operatorname{AET}(\mathrm{mm})$ & 0.11 & 0.01 & 0.28 & -0.67 & 0.17 & -0.17 & 0.13 & 0.71 & 0.66 & 0.67 & 0.45 \\
\hline $\mathrm{WD}(\mathrm{mm})$ & 0.47 & 0.56 & 0.20 & 0.93 & 0.07 & 0.72 & 0.19 & 0.25 & 0.26 & 0.18 & 0.39 \\
\hline $\mathrm{CWD}(\mathrm{mm})$ & -0.32 & -0.22 & -0.42 & 0.23 & -0.19 & -0.10 & -0.38 & -0.74 & -0.83 & -0.71 & -0.57 \\
\hline
\end{tabular}

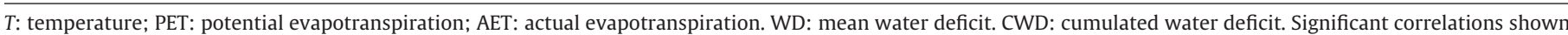
in bold $(p<0.05)$. 

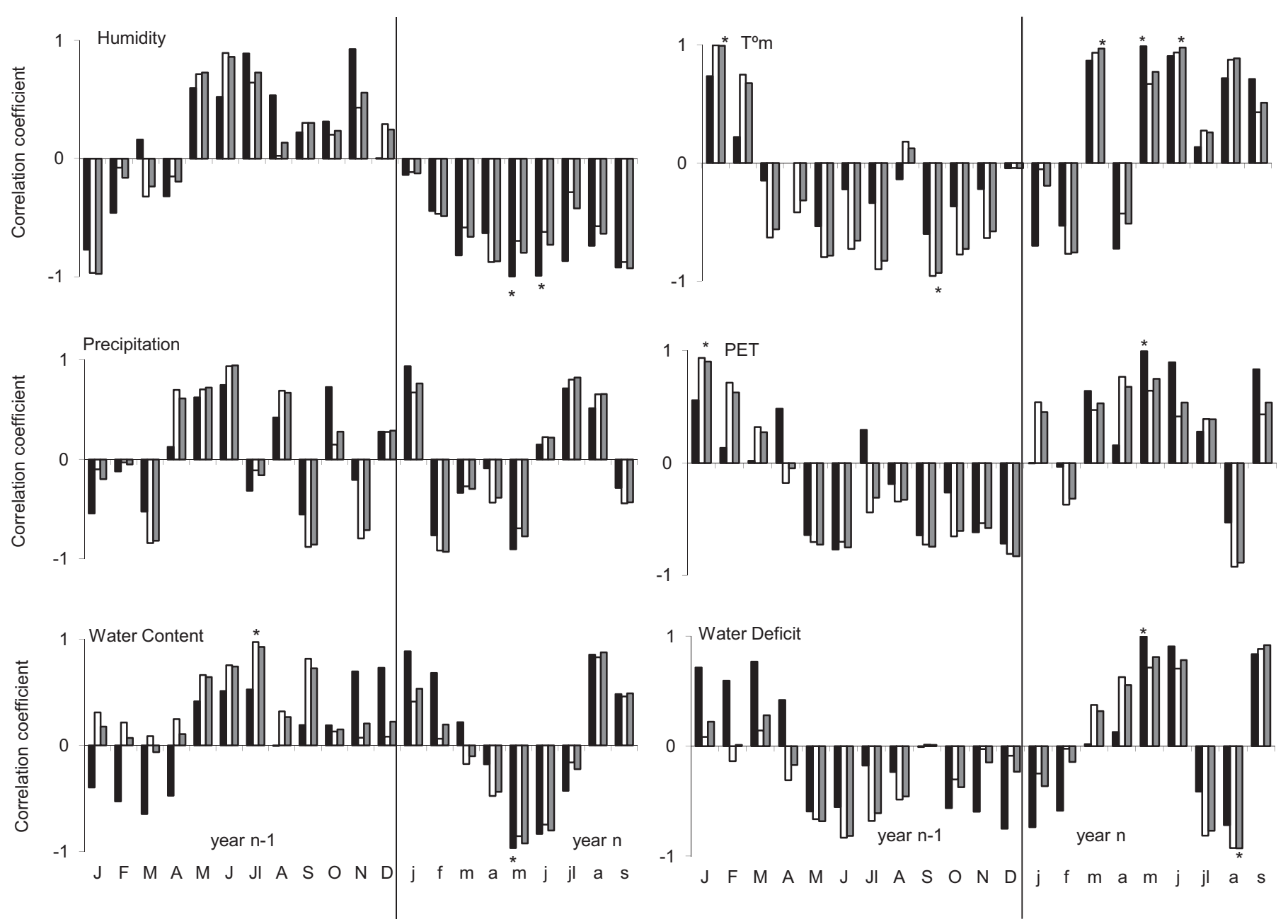

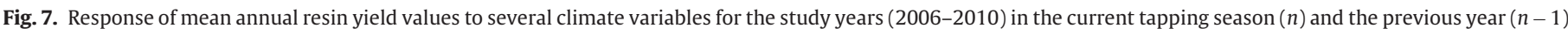

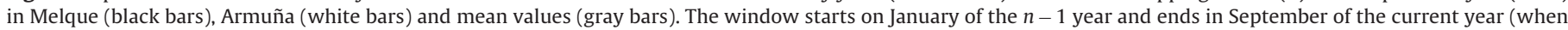

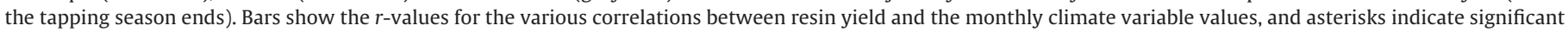
correlations ( $95 \%$ percentile range).

trend was similar to 2007 results, which showed positive relations to temperature and water deficit (Table 2). A comparison of the two locations (Table 2) shows that Armuña had stronger relations than Melque to most of the climate variables.

\subsubsection{Inter-annual analysis}

The variation of mean annual resin yield tended to be positively related to rainfall throughout the tapping season $(r=0.95$, $p=0.04$ ) (Fig. 3) and negatively related to the previous summer PET $(r=-0.98, p=0.02)$. For temperatures, positive relations $(p<0.05)$ were found for March, May and June in the current year and January of the previous year, whereas September temperatures of the previous year showed a negative relation to resin yield (Fig. 7). As a general trend, positive $r$-values were found in spring between resin yield and the variables PET and water deficit, but negative values related to water deficit in summer. A different trend was found for soil water content, with negative $r$-values in spring and positive in the previous-year summer (Fig. 7). Duration of aridity (a) did not show any significant relation with resin yield.

\subsection{Climate-anatomy relations}

The correlation analysis between climate and anatomical variables in tapped trees showed that growth ring width tended to be negatively related to summer temperatures $(r=-0.96, p=0.028$;
Fig. 4a), mainly due to the reduction of earlywood width $(r=-0.98$; $p=0.015$ ). The average values for both locations evidenced that years with higher rainfall in summer were associated with greater area and higher frequency of axial resin canals (Table 3). Lower spring AET and cumulated water deficit in winter were associated with higher area per $\mathrm{mm}^{2}$ of axial resin canals in tapped trees (Table 3). Higher soil water content in summer in the previous year seemed to produce greater area and higher frequency of axial resin canals, and lower water deficits in the previous year were also related to greater area of axial canals. For mean size of axial canals, a positive correlation $(p<0.05)$ was found with current season rainfall, summer soil water content and AET (Table 3 ).

When considering the locations separately, Melque showed a larger number of significant correlations $(p<0.05)$ with climate variables (7; Table 3 ) than Armuña (1) for the current year, but Armuña did so for the previous year (6 vs. 2 in Melque). In Melque, lower spring AET, higher temperatures and higher cumulated water deficits for the current year were related to greater area and higher frequency of axial canals (Table 3). Higher summer rainfall was also related to greater frequency of canals. In Armuña, the main relations were found for water status in the previous year, mostly in the summer months; higher water content and lower water deficit were associated to greater area and mean size of axial canals, respectively. Frosts in the previous year were also positively related to area and mean size of axial canals in this location (Table 3). Mean 
Table 3

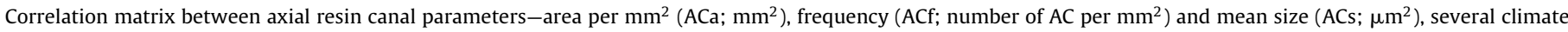

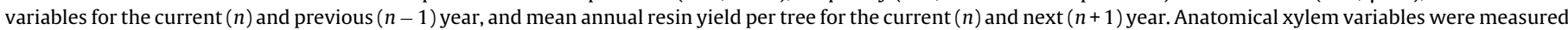
in the 2007-2010 growth rings of tapped $P$. pinaster trees.

\begin{tabular}{|c|c|c|c|c|c|c|c|c|c|c|}
\hline \multirow[t]{2}{*}{ Year } & \multirow[t]{2}{*}{ Climate variable } & \multicolumn{3}{|l|}{ Mean } & \multicolumn{3}{|c|}{ Armuña } & \multicolumn{3}{|c|}{ Melque } \\
\hline & & $\mathrm{ACa}$ & ACf & ACs & $\mathrm{ACa}$ & ACf & ACs & $\mathrm{ACa}$ & ACf & ACs \\
\hline \multirow[t]{8}{*}{$n$} & $T \max \left({ }^{\circ} \mathrm{C}\right)$ & 0.89 & 0.91 & -0.33 & 0.70 & 0.71 & 0.61 & 0.97 & 1.00 & -0.71 \\
\hline & Rainfall (mm) & -0.16 & -0.37 & 0.99 & -0.07 & -0.32 & 0.24 & -0.28 & -0.36 & 0.78 \\
\hline & Rainfall summer (mm) & 0.97 & 0.96 & -0.22 & 0.85 & 0.82 & 0.78 & 0.93 & 0.98 & -0.70 \\
\hline & WC summer $(\mathrm{mm})$ & -0.16 & -0.37 & 1.00 & -0.15 & -0.41 & 0.17 & -0.14 & -0.27 & 0.82 \\
\hline & $\operatorname{AET}(\mathrm{mm})$ & -0.44 & -0.63 & 0.95 & -0.40 & -0.63 & -0.10 & -0.40 & -0.53 & 0.94 \\
\hline & AET spring (mm) & -0.95 & -0.90 & 0.06 & -0.79 & -0.72 & -0.78 & -0.95 & -0.97 & 0.56 \\
\hline & $\mathrm{CWD}(\mathrm{mm})$ & 0.90 & 0.87 & -0.13 & 0.70 & 0.64 & 0.67 & 0.99 & 0.99 & -0.56 \\
\hline & CWD winter (mm) & -0.98 & -0.91 & -0.08 & -0.93 & -0.83 & -0.95 & -0.79 & -0.86 & 0.53 \\
\hline \multirow[t]{5}{*}{$n-1$} & $\mathrm{Cf}$ & 0.91 & 0.83 & 0.17 & 0.96 & 0.85 & 1.00 & 0.58 & 0.69 & -0.47 \\
\hline & Rainfall (mm) & 0.84 & 0.88 & -0.43 & 0.63 & 0.67 & 0.51 & 0.96 & 0.98 & -0.74 \\
\hline & WC summer (mm) & 0.99 & 0.96 & -0.07 & 0.97 & 0.91 & 0.93 & 0.77 & 0.87 & -0.66 \\
\hline & $\mathrm{WD}(\mathrm{mm})$ & -0.95 & -0.87 & -0.16 & -0.93 & -0.81 & -0.97 & -0.73 & -0.80 & 0.46 \\
\hline & CWD autum (mm) & -0.95 & -0.87 & -0.13 & -0.96 & -0.85 & -0.99 & -0.66 & -0.76 & 0.49 \\
\hline$n$ & Resin Yield (g/tree) & 0.23 & 0.07 & 0.17 & 0.04 & -0.14 & 0.20 & 0.36 & 0.29 & 0.19 \\
\hline$n+1$ & & 0.24 & 0.08 & 0.09 & -0.09 & -0.22 & 0.05 & 0.49 & 0.36 & 0.16 \\
\hline
\end{tabular}

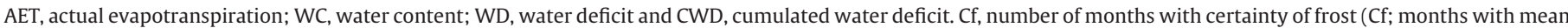
minimum $<0)$. Significant correlations shown in bold $(p<0.05)$.

lumen area of tracheids did not show any significant relation with climate variables.

\section{Discussion}

Resin production is a pivotal component of the defense system of conifers after various biotic or abiotic stimuli, providing a complex short- and long-term defense response (Lewinsohn et al., 1991; Moreira, 2010). In this study, the role of climate in regulating tree response (i.e., resin secretion) to the tapping wound was evaluated in two commercially tapped mature stands of maritime pine. The values of several climate factors acting during the tapping season and the previous year were found to be related to resin yield. Some of these relations were also associated with changes in the size and frequency of the secretory structures, which modulate the defense response of the plant (Franceschi et al., 2005; Krokene and Nagy, 2012).

\subsection{Intra-annual analysis}

Observation of the intra-annual results makes it possible to discuss the short-term effects of climate. During the tapping season, a high initial value for resin yield was observed as a consequence of the first tapping wound. This was less pronounced in the first year in Armuña, probably because the trees had not been tapped before (Rodríguez-García et al., 2014). During the first 15 days after wounding, the resin canal network preformed in the tree the previous year (constitutive and traumatic axial and radial resin canals) connected to the wounded zone starts to empty its contents under the effects of pressure and temperature (Schopmeyer et al., 1954; Lewinsohn et al., 1991) and the de novo resin synthesis process is activated 3-4 days after wounding (Ruel et al., 1998; Lombardero et al., 2000), although in P. taeda some studies have not been able to detect an induced resin flow with mechanical wounding alone (i.e., Klepzig et al., 2005). Resin flow decreases with the sealing of the small radial canals. A significant decrease in resin yield from the first to the second groove was observed every year in Melque and in the last two years in Armuña (Fig. 2). This decrease was not consistent with temperature variation, which increased $6.6^{\circ} \mathrm{C}$ in 2008 from the first to the second groove (Fig. 2). It was probably due to partial depletion of the constitutive resin stored in previous years and to higher investment in growth and reproduction than in defense processes, according to the growth-differentiation balance theroy (Lorio and Sommers, 1986; Herms and Mattson, 1992). Similarly, the increase in resin flow observed at the third and fourth groove could be explained by (i) outflow from new constitutive and traumatic resin canals (Ruel et al., 1998; Lieutier, 2004; Moreira, 2010; Krokene and Nagy, 2012); (ii) the influence of climate variables such as radiation, which allow the resin synthesis process to occur (Peñuelas and Llusia, 1999); and (iii) higher temperatures that allow longer flow times (Pardos et al., 1976) (Fig. 2). After the peak values reached in mid-summer, resin yield values started to decrease, probably due to the depletion of the resin canal network connected to the wounded zone.

Negative relations between plant physiological activity and summer droughts have been found in Mediterranean areas (Peñuelas and Llusia, 1999; de Luis et al., 2011; Vieira et al., 2014). When water deficit passes a certain threshold, xylem formation and the resin synthesis process may be limited. Recent studies showed that spring drought (May-June) is the primary factor limiting conifer growth in the Mediterranean (Lebourgeois et al., 2012; Vieira et al., 2014). Lower resin yield was observed in our results when cumulated water deficit reached $350-400 \mathrm{~mm}$ in August (Figs. 6a and 7). P. pinaster responds to water stress by isohydric behavior, closing its stomata to avoid hydraulic failure; this results in decreased carbohydrate availability (Ripullone et al., 2007; de Luis et al., 2007; Michelot et al., 2012). We observed negative effects of water deficit on resin yield in August (Fig. 7). These results indicate that water availability during summer could exert positive effects on resin flow. The last groove showed the lowest seasonal resin yield value in 2007 and 2010, but in 2008 at Melque and in 2009 at both locations, it showed higher values than the previous groove (Fig. 2). August rainfall was three times higher in 2008 and 2009 than in 2007 and 2010 (Fig. 1), suggesting that the higher resin yields in 2008 and 2009 (at the end of September) could be related to higher radiation (in 2009) and water content values that allow plants to invest in photosynthates, coinciding with a second period of growth described in autumn in Mediterranean zones (Camarero et al., 2010; Vieira et al., 2014).

\subsection{Inter-annual analysis}

Regarding the long-term climate effects, a positive effect of summer rainfall on the area and frequency of resin canals in the 
following year was observed (Table 3), as well as a positive relation between July water content and resin yield in the following year (Fig. 7). Recent studies in Mediterranean locations (Génova et al., 2014) showed similar results, with positive relations between summer rainfall and radial growth in tapped trees the following year. This variable is strongly related to axial canal frequency in Pinus (Rigling et al., 2003; Rodríguez-García et al., 2014) and also to resin yield (Rodrigues et al., 2008; Rodríguez-García et al., 2014).

Despite the positive effects of summer water availability on resin yield in the current and the following year, our results showed a positive relation between spring water deficit and resin yield (Table 2 and Fig. 7). These results could relate to the growthdifferentiation balance hypothesis during suboptimal conditions for growth, e.g. periods of moderate water stress; the lower availability of resources would slow down the plant physiological activity and the plant would encourage differentiation processes (e.g. biosynthesis of defensive compounds) at expense of growth processes (Ruel et al., 1998; Lombardero et al., 2000). In line of this hypothesis, Turtola et al. (2003) observed that severe droughts increased the concentration of several monoterpenes and resin acids in Scots pine.

Inter-annual analysis showed that resin yields in 2009 and 2010 were more closely related to radiation, whereas in 2007 and 2008 they were related to variables associated with water (Table 2). Higher soil water content at the beginning of the tapping season in 2007 and 2008 (Fig. 6b) could have favored storage of more photosynthetic products by less drought-stressed trees (Lorio and Sommers, 1986; Lewinsohn et al., 1993; Lombardero et al., 2000), showing lower dependence on light variables.

As we observed in the intra-annual results, climate effects coincided with the induced effects of tapping. For the inter-annual results, this is seen in the increase observed in resin flow and in the area and frequency of axial canals for the tapped trees in 2008 and 2009, compared with 2007, the first tapping year in Armuña and the second in Melque (Figs. 3 and 4b). The resin yield from the first groove in Melque in 2007 (second tapping year) was three times higher than the Armuña resin yield value (first tapped in 2007). These induced effects of the tapping wound could be explained by systemic induced resistance mechanisms (Ruel et al., 1998; Krokene and Nagy, 2012), resulting in increased resin flow (Lombardero et al., 2000; Bonello and Blodgett, 2003; Bonello et al., 2006; Moreira et al., 2009) and formation of new resin canals (Moreira et al., 2008; Rodríguez-García et al., 2014) in the years following tapping.

Comparison of the two pine stands shows that fluctuations in resin yield were in general more closely related to changes in climate variables in Armuña than in Melque (Table 2), where the trend was more homogeneous in all seasons (Figs. 2 and 3). Under a situation of more limited resource availability, such as the higher plant competition and lower soil water retention in Melque, the plastic response to favorable environmental variables could be hampered (Valladares et al., 2007). This lower plasticity in resin yield could be due to a genetic adaptation that establishes a lower capacity to synthesize and store secondary defense metabolites, resulting in lower resin flow fluctuations (Paine and Stephen, 1987; Mattson and Haack, 1987; Moreira et al., 2008; Esteban et al., 2010). The higher resin yield per tree found in Armuña, the stand with lower tree density, would support earlier work in lodgepole pine (Waring and Pitman, 1985), in which both tree vigor and resistance to bark beetle attacks increased when canopy density was reduced, suggesting that tree vigor could reflect the ability of trees to produce defensive compounds following attack. Neverthelees, other studies (Lorio and Sommers, 1986; McDowell et al., 2007; Knebel et al., 2008) demonstrated that resin flow could be increased even as growth decreased if reductions in photosynthesis were less than reductions in growth.

\subsection{Climate-anatomy relations}

The association found between resin yield and axial canal area (Table 3) suggests the important role that canal size plays in the process of resin exudation. Thus, the analysis of the relations between anatomical and climate variables may help explain some of the observed climate-resin yield relations. Earlier studies reported that high temperatures, aridity and cold winters were related to higher frequency and greater size of resin canals (Zamski, 1972; Rigling et al., 2003; Martín et al., 2010; Esteban et al., 2010). Ethylene appears to play a key role in linking exogenous factors that induce ethylene production and resin canal formation. The two principal factors inducing ethylene production are extreme temperatures and drought (Abeles et al., 1992; Esteban et al., 2012). This could explain the correlation observed between the frequency and area per $\mathrm{mm}^{2}$ of axial canals and the climate variables related to extreme temperatures and drought: cumulated water deficit, maximum temperatures and number of certain frost months in the previous year (Table 3).

As with the resin yield, for the rainfall variable we found that axial canal area and axial canal frequency were positively related to summer rainfall, although other authors reported a negative relation between these parameters (Wimmer and Grabner, 1997; Rigling et al., 2003). These studies were conducted in Atlantic climates, whereas in our Mediterranean study location, summer droughts are a major stress factor that limits xylem formation processes (Vieira et al., 2014).

\section{Conclusion}

Decades of tapping activity have adjusted the tapping season to the most climatically favorable months. However, some conclusions and suggestions for management can be deduced from our results: (i) The significant relationships found between resin yield and the climatic variables temperature, radiation and PET point out the expected higher resin flows in the warmest months; (ii) since prolonged summer drought in the Mediterranean climate limits plant metabolism, extreme summer droughts in the Mediterranean area would probably have negative effects on both resin yield and tree defense against bark boring insects, even if the resin flow could be increased by high radiation and temperatures; (iii) in years with a rainy summer and/or dry spring, a slightly longer tapping season could be suggested, as resin yield increases after these events; and (iv) under adverse climate scenarios where resource optimization is desirable, a reduced tapping season during the warmest months (June-September) would be advisable, assuming a very small production loss.

Global warming and the increasing demand for natural resin make it necessary to have information available about the effects of climate on resin yield and forest health for the management of resin tapping forests. The features of the Mediterranean climate, combined with the effects of climate change such as extreme droughts and atypical heavy rainfall in summer, are limiting factors for other land uses, but they could be an opportunity for a multiple-purpose forestry activity like resin tapping as a way to offset potential scenarios of financial loss. Forest policies should include this kind of forest use in management plans and ecological restoration in regions within the distribution area of $P$. pinaster where tapping can be a good choice for rural development and the conservation of ecosystem services.

\section{Acknowledgements}

The authors are grateful to the Forestry Services and Promotion Centre of Castilla y León (CESEFOR) for providing technical 
assistance and resin yield data. This study was funded by the Spanish Ministry of Agriculture, Food and Environment as part of the European Cooperation project REMASA for the improvement of the resin sector in rural areas, and the European project StarTree "Multipurpose trees and non-wood forest products a challenge and opportunity", funded by the European Union through the European Commission's FP7 Cooperation Work Programme under grant agreement no. 311919. The authors are grateful to two anonymous reviewers for reviewing the manuscript, making suggestions and providing a critique and to Jane McGrath for the language editing.

\section{References}

Alía, R., Gil, L., Pardos, J.A., 1995. Performance of 43 Pinus pinaster Ait. provenances on 5 locations in central Spain. Silvae Genet. 44 (2), 75-80.

Abeles, B., Morgan, P.W., Saltveit Jr., M.E., 1992. Ethylene in Plant Biology. Academic Press., San Diego, California.

Baier, P., Fuhrer, E., Kirisits, T., Rosner, S., 2002. Defence reactions of Norway spruce against bark beetles and the associated fungus Ceratocystis polonica in secondary pure and mixed species stands. For. Ecol. Manage. 159, 73-86, http://dx.doi.org/10.1016/s0378-1127(01)00711-3.

Ballesteros, J.A., Stoffel, M., Bodoque, J.M., Bollschweiler, M., Hitz, O., DiezHerrero, A., 2010. Changes in wood anatomy in tree rings of Pinus pinaster Ait. following wounding by flash floods. Tree-Ring Res. 66 (2), 93-103, http://dx.doi.org/10.3959/2009-4.1.

Blanche, C.A., Lorio, P.L., Sommers, R.A., Hodges, J.D., Nebeker, T.E., 1992. Seasonal cambial growth and development of loblolly-pine: xylem formation, inner bark chemistry, resin ducts, and resin flow. For. Ecol. Manage. 49 (1-2), 151-165, http://dx.doi.org/10.1016/0378-1127(92)90167-8.

Bonello, P., Blodgett, J.T., 2003. Pinus nigra-Sphaeropsis sapinea as a model pathosystem to investigate local and systemic effects of fungal infection of pines. Physiol. Mol. Plant Pathol. 63 (5), 249-261, http://dx.doi.org/10.1016/j.pmpp.2004.02.002.

Bonello, P., Gordon, T.R., Herms, D.A., Wood, D.L., Erbilgin, N., 2006. Nature and ecological implications of pathogen-induced systemic resistance in conifers: a novel hypothesis. Physiol. Mol. Plant Pathol. 68 (4-6), 95-104, http://dx.doi.org/10.1016/j.pmpp.2006.12.002.

Boschiero, Ferreira A.T., Tomazzello-Filho, M., 2012. Anatomical aspects of resin canals and oleoresin production in pine trees. In: Fett-Neto, A.G., RodriguesCorrêa, K.C.S. (Eds.), Resin: Biology, Chemistry and Applications, Research Signpost. Research Signpost, Kerala, India, pp. 67-86.

Botey, R., Moreno, J.V., Pérez, J., 2009. Monitorización de la humedad del suelo en tres observatorios meteorológicos (campaña 2007-2008). AEMET, Ministerio de Medio Ambiente y Medio Rural y Marino, 102 paíg.

Bravo-Oviedo, A., del Río, M., Montero, G., 2007. Geographic variation and parameter assessment in generalized algebraic difference site index modelling. For. Ecol. Manage. 247 (1), 107-119.

Camarero, J.J., Olano, J.M., Parras, A., 2010. Plastic bimodal xylogenesis in conifers from continental Mediterranean climates. New Phytol. 185 (2), 471-480.

Croteau, R., Gurkewitz, S., Jonson, M.A., Fisk, H.J., 1987. Biochemistry of oleoresinosis: monoterpene and diterpene biosynthesis in lodgepole pine saplings infected with Ceratocystis clavigera or treated with carbohydrate elicitors. Plant Physiol. 85 (4), 1123-1128, http://dx.doi.org/10.1104/pp.85.4.1123.

Cunningham, A., 2013. Estudio de mercado de la resina, 〈http://areldorado. com.ar/statistics/charts/areldorado_all_charts.pdf).

De Luis, M., Gricar, J., Cufar, K., Raventós, J., 2007. Seasonal dynamics of wood formation in Pinus halepensis from dry and semi-arid ecosystems in Spain. IAWA J. 28 (4), 389.

De Luis, M., Nova, K., Raventós, J., Gričar, J., Prislan, P., Čufar, K., 2011. Cambial activity, wood formation and sapling survival of Pinus halepensis exposed to different irrigation regimes. For. Ecol. Manage. 262 (8), 1630-1638.

Esteban, L.G., Martín, J.A., de Palacios, P., Fernández, F.G., López, R., 2010. Adaptive anatomy of Pinus halepensis trees from different Mediterranean environments in Spain. Trees 24 (1), 19-30.

Esteban, L.G., Martín, J.A., de Palacios, P., Fernández, F.G., 2012. Influence of region of provenance and climate factors on wood anatomical traits of Pinus nigra Arn. subsp. salzmannii. Eur. J. For. Res. 131 (3), 633-645.

FAO, 1998. Crop evapotranspiration-guidelines for computing crop water requeriments. In: FAO Irrigation and Drainage Paper 56. FAO, Roma, pp. 298.

Franceschi, V.R., Krekling, T., Christiansen, E., 2002. Application of methyl jasmonate on Picea abies (Pinaceae) stems induces defense-related responses in phloem and xylem. Am. J. Bot. 89 (4), 578-586, http://dx.doi.org/10.3732/ajb.89.4.578.

Franceschi, V.R., Krokene, P., Christiansen, E., Krekling, T., 2005. Anatomical and chemical defenses of conifer bark against bark beetles and other pests. New Phytol. 167 (2), 353-375, http://dx.doi.org/10.1111/j.1469-8137.2005.01436.x.

Gaylord, M.L., Kolb, T.E., Wallin, K.F., Wagner, M.R., 2007. Seasonal dynamics of tree growth, physiology, and resin defenses in a northern Arizona pine forest. Can. J. For. Res. 37, 1173-1183.

Génova, M., Caminero, L., Dochao, J., 2014. Resin tapping in Pinus pinaster: effects on growth and response function to climate. Eur. J. For. Res. 133 (2), 323-333 (Fuera de serie 1).
Gil, L., Gordo, L., Alía, R., Pardos, J., 1990. Pinus pinaster Aiton en el paisaje vegetal de la Península Ibérica. Ecología Fuera de serie 1, 469-496.

Gil, L., López, R., García-Mateos, Á., González-Doncel, I., 2010. Seed provenance and fire-related reproductive traits of Pinus pinaster in central Spain. Int. J. Wildland Fire 18 (8), 1003-1009.

Giorgi, F., Lionello, P., 2008. Climate change projections for the Mediterranean region. Global Planet. Change 63 (2), 90-104.

Hall, D.E., Zerbe, P., Jancsik, S., Quesada, A.L., Dullat, H., Madilao, L.L., Bohlmann, J. 2013. Evolution of conifer diterpene synthases: diterpene resin acid biosynthesis in lodgepole pine and jack pine involves monofunctional and bifunctional diterpene synthases. Plant Physiol. 161 (2), 600-616.

Hanson, E.J., Azuma, D.L., Hiserote, B.A., 2003. Site Index Equations and Mean Annual Increment Equations for Pacific Northwest Research Station Forest Inventory and Analysis Inventories, 1985-2001. In: Research Note. U.S. Department of Agriculture, Pacific Northwest Research Station, Portland.

Heijari, J., Nerg, A.M., Kainulainen, P., Viiri, H., Vuorinen, M., Holopainen, J.K., 2005 Application of methyl jasmonate reduces growth but increases chemical defence and resistance against Hylobius abietis in Scots pine seedlings. Entomol. Exp. Appl. 115 (1), 117-124.

Herms, D.A., Mattson, W.J., 1992. The dilemma of plants: to grow or defend. Q. Rev. Biol. 67 (3), 283-335, http://dx.doi.org/10.1086/417659.

Hernández, L., 2006. El antiguo oficio de resinero. In: Hojas divulgadoras. No. 2116 HD. Ministerio de agricultura, pesca y alimentación, Madrid.

Hodges, J.D., Elam, W.W., Watson, W.F., Nebeker, T.E., 1979. Oleoresin characteristics and susceptibility of four southern pines to southern pine beetle (Coleoptera: Scolytidae) attacks. Can. Entomol. 111 (08), 889-896.

Kim, J.C., Kim, K.J., Kim, D.S., Han, J.S., 2005. Seasonal variations of monoterpene emissions from coniferous trees of different ages in Korea. Chemosphere 59, 1685-1696.

Klepzig, K.D., Robison, D.J., Fowler, G., Minchin, P.R., Hain, F.P., Allen, H.L., 2005. Effects of mass inoculation on induced oleoresin response in intensively managed loblolly pine. Tree Physiol. 25 (6), 681-688.

Knebel, L., Robison, D.J., Wentworth, T.R., Klepzig, K.D., 2008. Resin flow responses to fertilization, wounding and fungal inoculation in loblolly pine (Pinus taeda) in North Carolina. Tree Physiol. 28 (6), 847-853.

Kolosova, N., Bohlmann, J., 2012. Conifer defenses against insects and pathogens In: Schnyder, H., Oßwald, W. (Eds.), Growth and Defense in Plants: Resource Allocation at Multiple Scales, vol. 220. Springer, Berlin, pp. 85-109.

Krokene, P., Nagy, N.E., 2012. Anatomical aspects of resin-based defences in pine. In: Fett-Neto, A.G., Rodrigues-Corrêa, K.C.S.(Eds.), Pine Resin: Biology, Chemistry and Applications. Research Signote, Kerala, India, pp. 67-86.

Langenheim, J.H., 2003. Plant Resins: Chemistry, Evolution, Ecology, and Ethnobotany. Timber Press, Portland, OR, ISBN 0-881925-748.

Lebourgeois, F., Mérian, P., Courdier, F., Ladier, J., Dreyfus, P., 2012. Instability of climate signal in tree-ring width in Mediterranean mountains: a multi-species analysis. Trees 26 (3), 715-729.

Lev-Yadun, S., 2002. The distance to which wound effects influence the structure of secondary xylem of decapitated Pinus pinea. J. Plant Growth Regul. 21 (2), 191-196, http://dx.doi.org/10.1007/s003440010057.

Lewinsohn, E., Gijzen, M., Croteau, R., 1991. Defense-mechanisms of conifers-differences in constitutive and wound-induced monoterpene biosynthesis among species. Plant Physiol. 96 (1), 44-49, http://dx.doi.org/10.1104/pp.96.1.44.

Lewinsohn, E., Savage, T.J., Gijzen, M., Croteau, R., 1993. Simultaneous analysis of monoterpenes and diterpenoids of conifer oleoresin. Phytochem. Anal. 4 (5), 220-225.

Lieutier, F., 2004. Host Resistance to Bark Beetles and its Variations in Bark and Wood Boring Insects in Living Trees in Europe: A Synthesis. Springer, Netherlands, pp. $135-180$.

Lombardero, M.J., Ayres, M.P., Lorio, P.L., Ruel, J.J., 2000. Environmental effects on constitutive and inducible resin defences of Pinus taeda. Ecol. Lett. 3(4), 329-339, http://dx.doi.org/10.1046/j.1461-0248.2000.00163.x.

Lorio, P.L., Sommers, R.A., 1986. Evidence of competition for photosynthates between growth processes and oleoresin synthesis in Pinus taeda. Tree Physiol. $2(1-3), 301-306$.

Luchi, N., Ma, R., Capretti, P., Bonello, P., 2005. Systemic induction of traumatic resin ducts and resin flow in Austrian pine by wounding and inoculation with Sphaeropsis sapinea and Diplodia scrobiculata. Planta 221 (1), 75-84, http://dx.doi.org/10.1007/s00425-004-1414-3.

Martin, D., Tholl, D., Gershenzon, J., Bohlmann, J., 2002. Methyl jasmonate induces traumatic resin ducts, terpenoid resin biosynthesis, and terpenoid accumulation in developing xylem of Norway spruce stems. Plant Physiol. 129(3), 1003-1018, http://dx.doi.org/10.1104/pp.011001.

Martín, J.A., Esteban, L.G., de Palacios, P., Fernández, F.G., 2010. Variation in wood anatomical traits of Pinus sylvestris L. between Spanish regions of provenance. Trees 24 (6), 1017-1028.

Mattson, W.J., Haack, R.A., 1987. The role of drought in outbreaks of plant-eating insects. BioScience 37 (2), 110-118.

McDowell, N.G., Adams, H.D., Bailey, J.D., Kolb, T.E., 2007. The role of stand density on growth efficiency, leaf area index, and resin flow in southwestern ponderosa pine forests. Can. J. For. Res. 37 (2), 343-355.

Michelot, A., Simard, S., Rathgeber, C., Dufrêne, E., Damesin, C., 2012. Comparing the intra-annual wood formation of three European species (Fagus sylvatica, Quercus petraea and Pinus sylvestris) as related to leaf phenology and non-structural carbohydrate dynamics. Tree Physiol. 32 (8), 1033-1045. 
Morales-Molino, C., Postigo-Mijarra, J.M., Morla, C., García-Antón, M., 2012. Longterm persistence of Mediterranean pine forests in the Duero basin (central Spain) during the Holocene: the case of Pinus pinaster Aiton. Holocene 22 (5), 561-570.

Moreira, X.Q. Sampedro, L., Zas, R. Solla, A., 2008. Alterations of the resin canal system of Pinus pinaster seedlings after fertilization of a healthy and of a Hylobius abietis attacked stand. Trees 22 (6), 771-777, http://dx.doi.org/10.1007/s00468-008-0237-4.

Moreira, X., Sampedro, L., Zas, R., 2009. Defensive responses of Pinus pinaster seedlings to exogenous application of methyl jasmonate: concentration effect and systemic response. Environ. Exp. Bot. 67 (1), 94-100, http://dx.doi.org/10.1016/j.envexpbot.2009.05.015.

Moreira, X., 2010. Variación genética y efecto de la disponibilidad de nutrientes en las defensas constitutivas e inducidas de Pinus pinaster Ait. Departamento de Ingeniería de los Recursos Naturales y Medioambiente, Universidade de Vigo, pp. 18-26 (Ph.D. Thesis).

Moreira, X., Zas, R., Sampedro, L., 2012. Differential allocation of constitutive and induced chemical defenses in pine tree juveniles: a test of the optimal defense theory. PLoS One 7 (3), e34006.

Mumm, R., Hilker, M., 2006. Direct and indirect chemical defence of pine against folivorous insects. Trends Plant Sci. 11, 351-358.

Mutke, S., Gordo, J., Gil, L., 2005. Variability of Mediterranean stone pine cone yield: yield loss as response to climate change. Agric. For. Meteorol. 132 (3/4), 263-272.

Mutke, S., García Del Barrio, J.M., Martínez Jauregui, M., Soliño, M., de Miguel, J. Justes, A., Ruiz Peinado, R., del Río, M., Auñón, F., Alía, R., Chambel, R., Herruzo, C., Sánchez de Ron, D., Alonso, C., 2013. Bases para buenas prácticas en la gestión del aprovechamiento resinero. INIA, Madrid, pp. 96, ISBN 978-84-7498-556-6.

Nagy, N.E., Franceschi, V.R., Solheim, H., Krekling, T., Christiansen, E., 2000 Wound-induced traumatic resin duct development in stems of Norway spruce (Pinaceae): anatomy and cytochemical traits. Am. J. Bot. 87, 302-313.

Nanos, N., Tadesse, W., Montero, G., Gil, L., Alía, R., 2000. Modelling resin production distributions for Pinus pinaster Ait using two probability functions. Ann. For. Sci 57 (4), 369-377.

Nanos, N., Tadesse, W., Montero, G., Gil, L., Alía, R., 2001. Spatial stochastic modeling of resin yield from pine stands. Can. For. Res. 31 (7), 1140-1147.

Novick, K.A., Katul, G.G., McCarthy, H.R., Oren, R., 2012. Increased resin flow in mature pine trees growing under elevated $\mathrm{CO}_{2}$ and moderate soil fertility. Tree Physiol. 32, 725-763, http://dx.doi.org/10.1093/treephys/tpr133.

O’Neill, G.A., Aitken, S.N., King, J.N., Alfaro, R.I., 2002. Geographic variation in resin canal defenses in seedlings from the Sitka spruce $\times$ white spruce introgression zone. Can. J. For. Res. 32 (3), 390-400.

Paine, T.D., Stephen, F.M., 1987. Fungi associated with the southern pine beetle: avoidance of induced defense response in loblolly pine. Oecologia 74 (3), 377-379.

Pardos, J.A., Solis, W., Moro, J., 1976. Estudio de las variaciones estacionales de la presión de exudación de la resina en árboles, grandes productores y de producción media. In: Comunicaciones INIA, Serie Recursos Naturales, No. 4,29. Instituto Nacional de Investigaciones Agrarias, Madrid.

Peñuelas, J., Llusia, J., 1999. Short-term responses of terpene emission rates to experimental changes of PFD in Pinus halepensis and Quercus ilex in summer field conditions. Environ. Exp. Bot. 42 (1), 61-68.

Phillips, M.A., Croteau, R.B., 1999. Resin-based defense in conifers. Trends Plant Sci. 4 (5), 184-190, http://dx.doi.org/10.1016/s1360-1385(99)01401-6.

Pio, C.A., Valente, A.A., 1998. Atmospheric fluxes and concentrations of monoterpenes in resin-tapped pine forest. Atmos. Environ. 32, 683-691.
Rigling, A., Bruhlhart, H., Braker, O.U., Forster, T., Schweingruber, F.H., 2003. Effects of irrigation on diameter growth and vertical resin duct production in Pinus sylvestris on dry sites in the Central Alps, Switzerland. For. Ecol. Manage. 175, 285-296, http://dx.doi.org/10.1016/s0378-1127(02)00136-6.

Ripullone, F., Guerrieri, M.R., Magnani, F., Nole', A., Borghetti, M., 2007. Stomatal conductance and leaf water potential responses to hydraulic conductance variation in Pinus pinaster seedlings. Trees (Berl.) 21, 371-378, http://dx.doi.org/10.1007/s00468-007-0130-6.

Roberds, J.H., Strom, B.L., Hain, F.P., Gwaze, D.P., McKeand, S.E., Lott, L.H., 2003. Estimates of genetic parameters for oleoresin and growth traits in juvenile loblolly pine. Can. J. For. Res. 33 (12), 2469-2476.

Rodrigues, K.C.S., Azevedo, P.C.N., Sobreiro, L.E., Pelissari, P., Fett-Neto, A.G., 2008 Oleoresin yield of Pinus elliottii plantations in a subtropical climate: effect of tree diameter, wound shape and concentration of active adjuvants in resin stimulating paste. Ind. Crops Prod. 27 (3), 322-327.

Rodrigues, K.C.S., Fett-Neto, A.G., 2012. Physiological control of pine resin production. In: Fett-Neto, A.G., Rodrigues-Corrêa, K.C.S. (Eds.), Pine Resin: Biology, Chemistry and Applications. Research Signpost, Kerala, India, pp. 9-24.

Rodríguez-García, A., López, R., Martín, J.A., Pinillos, F., Gil, L., 2014. Resin yield in Pinus pinaster is related to tree dendrometry, stand density and tapping-induced systemic changes in xylem anatomy. For. Ecol. Manage. 313, 47-54

Ruel, J.J., Ayres, M.P., Lorio, P.L., 1998. Loblolly pine responds to mechanical wounding with increased resin flow. Can. J. Bot. 28 (4), 596-602, http://dx.doi.org/10.1139/cjfr-28-4-596.

Schopmeyer, C.S., Mergen, F., Evans, T.C., 1954. Applicability of Poiseuille's law to exudation of oleoresin from wounds on slash pine. Plant Physiol. 29 (1), 82

Terrado, M., Acuña, V., Ennaanay, D., Tallis, H., Sabater, S., 2014. Impact of climate extremes on hydrological ecosystem services in a heavily humanized Mediterranean basin. Ecol. Indic. 37, 199-209.

Thornthwaite, C.W., Mather, J.R., 1957. Instructions and Tables for Computing Potential Evapotranspiration and the Water Balance. Pub. Climatology 10, 185-311.

Tingey, D.T., Manning, M., Grothaus, L.C., Burns, W.F., 1980. Influence of light and temperature on monoterpene emission rates from slash pine. Plant Physiol. 65 (5), 797-801.

Turtola, S., Manninen, A.M., Rikala, R., Kainulainen, P., 2003. Drought stress alters the concentration of wood terpenoids in Scots pine and Norway spruce seedlings. J. Chem. Ecol. 29 (9), 1981-1995.

Valbuena-Carabaña, M., de Heredia, U.L., Fuentes-Utrilla, P., González-Doncel, I., Gil L., 2010. Historical and recent changes in the Spanish forests: a socio-economic process. Rev. Palaeobot. Palynol. 162 (3), 492-506.

Valladares, F., Gianoli, E., Gómez, J.M., 2007. Ecological limits to plant phenotypic plasticity. New Phytol. 176 (4), 749-763.

Vieira, J., Rossi, S., Campelo, F., Freitas, H., Nabais, C., 2014. Xylogenesis of Pinus pinaster under a Mediterranean climate. Ann. For. Sci. 71 (1), 71-80.

Waring, R.H., Pitman, G.B., 1985. Modifying lodgepole pine stands to change susceptibility to mountain pine beetle attack. Ecology. 66, 889-897.

Water Conservation Factsheet, 2002. Order No.619.000-1. Water Conservation Factsheet, Abbotsford, BC Canada (Revised February 2002. Agdex: 550)

Wimmer, R., Grabner, M., 1997. Effects of climate on vertical resin duct density and radial growth of Norway spruce Picea abies (L) karst. Trees 11 (5), 271-276, http://dx.doi.org/10.1007/pl00009673.

Zamski, E., 1972. Temperature and photoperiodic effects on xylem and vertical resin duct formation in Pinus halepensis Mill. Isr. J. Bot. 21, 99-102. 